Journal of Humanities, Social and Management Sciences (JHSMS)

https:// doi.org/10.47264/idea.jhsms/1.1.4

Vol. 1, No. 1 (January-December 2020), 44-52

https://www.ideapublishers.org/index.php/jhsms

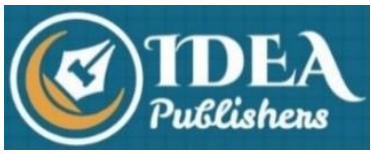

Research Article

\title{
Pakistan's Exertions of Reconciliation between Iran and Saudi Arabia: Challenges and Opportunities
}

\author{
Sania Zehraa*1, Ayesha Imtiaz ${ }^{1}$ and Jawad Ahmed ${ }^{2}$
}

1. Department of Politics \& International Relations, International Islamic University, Islamabad, Pakistan

2. School of Law and Economics, University of Kassel, Kassel, Hessen, Germany.

* Corresponding Author Email: sania.iiui514@gmail.com

\begin{abstract}
The Middle East is experiencing a period of progressive change that is testing the international strategies of every single local state. In this new condition, openings and difficulties exist for various territorial and extra-local states to propel their national advantages, while endeavouring to minimize those of their adversaries. One of the most significant contentions characterizing the vital scene of the Middle East is Saudi-Iran relations. Saudi Arabia and Iran have frequently carried on as genuine adversaries for impact in the Middle East. Pakistan is partner of both states and attempting to arbitrate between them for territorial harmony and congruity. The point of the accompanying work is to examine the Saudi-Iranian competition and endeavours of conciliation of Pakistan between two. This paper aims to explore the new developments in Saudi-Iranian relations and their impact on Middle East. This research is descriptive and analytical. It is qualitative research and secondary methods such as books, articles, journals, newspapers, and magazines have been utilized. The study analyses and examines the role of Pakistan as a mediator between both respective states and how Iran and Saudi Arabia's quest for regional hegemony may impact the Middle East and Pakistan.
\end{abstract}

Keywords: Pakistan, Iran, Saudi Arabia, Middle East, Iran-Saudi Rivalry, Geo-Economy, Conflict Management, Security.

\section{How to Cite:}

Zehra, S., Imtiaz, A., \& Ahmad, J. (2020). Pakistan's Exertions of Reconciliation between Iran and Saudi Arabia: Challenges and Opportunities. Journal of Humanities, Social and Management Sciences (JHSMS), 1(1), 44-52. https://doi.org/10.47264/idea.jhsms/1.1.4

\section{Publisher's Note:}

IDEA PUBLISHERS (IDEA Journals Group) stands neutral regarding jurisdictional claims in the published maps and institutional affiliations.

\section{Copyright:}

(c) 2020 The Author(s), published by IDEA PUBLISHERS (IDEA Journals Group)

This is an Open Access article published under the Creative Commons Attribution-NonCommercial 4.0 International License (http://creativecommons.org/licenses/by-nc/4.0/) 


\section{Introduction}

Pakistan marks a history of good relations with Iran as a neighbour and Saudi Arabia as long time tested friend. Iran became the first state to officially recognize Pakistan whereas Saudi Arabia is a strategic ally of Pakistan. Iran and Saudi Arabia both are very important in the Middle Eastern region. Their bilateral relations never seemed to be normal especially after the Islamic revolution of 1979 . The two states reached at the verge of rivalry where the friend of one is perceived as the enemy of other and are stuck in a zero-sum game. Meanwhile Pakistan is trying hard to maintain a balance in pursuing foreign policy with both rivals. This topic can be explained better under the theory of Conflict Management, which determines to control a conflict by understanding its nature and preventing it from further prolonging. The different tools, which can be used for conflict management, are negotiations, facilitation, and mediation by a third state to melt the ice between the states that are not even on talking terms. Since, Pakistan is considered to have close ties with both Middle Eastern rivals; it can play a very crucial role between these two Muslim states in the same region with bitter rivalry. Many papers have been published on the nature of rivalry between Kingdom of Saudi Arabia (KSA) and Iran but only a few examined their implications for Pakistan, which is like a sandwich and always struggling to adopt a balanced approach.

Most scholars distinguish Saudi-Iranian contention in the Middle East and its overflow into Pakistan as one of the fundamental purposes behind the ascent of this ace in Pakistan. In the event that Pakistan can assume a job in decreasing Saudi-Iranian pressures, it could likewise advance partisan congruity in Pakistan. Then again, a choice to favour either side would produce dishonesty a societal pressures in the nation. Much greater risk for Pakistan is financial. Pakistan is accepted to be on the cusp of a financial turnaround. Aided by GDP development rate, increment in outside settlements and lower oil costs, the economy has made some great walks lately.

\section{Iran-Saudi Rivalry}

Saudi Arabia and Iran are carrying centuries old national cultural and religious superiority and view each other as an enemy. Furthermore both have been struggling for the Muslim World leadership but ethnic as well as ideological differences make clashes between them. Currently Iran and Saudi Arabia's rivalry is the power struggle in Middle East to become the leader of the Muslim world. The $21^{\text {st }}$ century transformed the paradigms of conflict between the both countries into an ever growing quest for power in the regional hegemony. Despite historical difference of Arab and Ajam, before Islamic revolution in Iran, their relations were somehow good and they worked for regional stability and peace more or less. At that, time of peace both were monarchs and USA alliances was a major reason behind good relations.

Saudi Arabia's rhetoric in the Muslim world is most acceptable because it is the guardian of the Holy Mosques of Mecca and Madina. In 1736, Safavids successfully got control of Persia from Mongols where Shi'ism became the religion of the state. Later in 1920's Qajar dynasty was overthrown by Reza Khan who seemed to be inspired by Kamal Ataturk's secular Turkey. The formation of a central government Reza Khan was perceived a threat by Arabs and struggle for regional hegemony was at peak between them. Later shah annexed the Khuzistan with Iran, which was the matter of great concern for Saudi king Adbul Aziz. Later on, Reza shah Pahlavi's son replaced him and new shah tried to established good relations with Saudi Arabia. Saudi 
Pakistan's Exertions of Reconciliation between Iran and Saudi Arabia: Challenges and ...

Arabia felt alarming by the involvement of Iran in Baghdad Pact in 1955. But, both states started a period of better bilateral terms for relatively larger gains. King Faisal's accession had marked a fresh history of good relations with positive developments in the region till the Iranian revolution. Both monarchs had good ties with west and were getting support by USA president "Twin Pillar" strategy. (Khan, 2001).

After the Iranian revolution in 1979 substantial events took place as Reza shah Phalavi was overthrown by Islamists and Ayatollah Khomeini established new Islamic republic. After Islamic revolution, Iran adopted a policy to spread out the ideology of revolution in Persian Gulf and made a call of "End of Monarchy" along with anti-USA and anti-Israel slogans. Hence, the overthrow of monarchy was also disturbing for Saudi Arabia and it perceived the revolutionary call as a threat. Gulf monarchical regimes got annoyed with Iran and decided to isolate it diplomatically. Consequently, two regimes were established with growing enmity and different ideologies. Post Iranian revolution marked a new phase of cold relations between both the states where they never indulged in direct wars but the nature of tensions was similar to the Cold War between USA and USSR. Saudi Arab was sustaining its monarchy and making alliances while Iran as a revisionist state was preaching its revolutionary message. For this purpose both regional powers used their religious ideologies as a tool to pursue their interests by inducing proxy wars in the region rather than direct confrontation which required more military and economic expenditures. Vali Nasr writes that consequently "The band of radical Islam that began spreading across Central Asia and the Caucasus in the 1990s was radicalism born of the deliberate Saudi policy of containing Iran" (Nasr, 2006, p. 5).

Shah of Iran was under much influence of the west, which changed the Iranian society secular. Later Imam Khomeini became the supreme leader of Iran because he led the revolutionary thoughts in Iran and spread these ideas in Iranian society through his great leadership skills. He started disobedience towards western policies (Calvocrecci, 2001, p.381). The decline of Ottoman Empire, Iranian revolution, the USA incursion of Iraq and Arab uprising since 2011 are the important events that increased rivalry between Saudi Arabia and Iran. The aim of both the states is attracting global economy and creating influence in Persian Gulf.

\section{Implications for Pakistan}

The rivalry between Saudi Arabia and Iran has created a division not only in the Middle East but it has also created a far greater impact for the other Muslim countries as well. Pakistan is one that state which always tried to remain neutral and develop cordial ties with both rivals although it had been a toughest job under the political dynamics of the region of Middle East particularly KSA and Iran. Iran and Pakistan have friendly ties on the basis of culture, religion and most importantly geographic proximity (Sattar, 2013). The important pillar of strengthening ties was signing defense pact of CENTO. Later Regional Cooperation and Development (RCD) brought both states even more closely. Iran extended its great support during Indo-Pak wars $(1965,1971)$. During the war between Iran and Iraq, Pakistan refused to support Iraq as it could hamper their bilateral relations. Saudi Arabia also provided Pakistan great help during war with India and always stands with Pakistan in the hour of need.

Despite Pakistan's utmost efforts, striking a balance between both states is not an easy task because of the nature of animosity and rivalry of their relations. Pakistan shares immediate border with Iran and contains second highest Shia population after Iran. Bringing Iran to the 
point of disagreement can provoke sectarian violence in Pakistan something, which is not affordable for Pakistan because of its own geo-economic factors.

After Iranian Islamic revolutions, the relations between Iran and USA got intensified. However, Pakistan became an ally of U.S during Afghan war. Saudi Arabia and USA nexus adds more difficulties for Pakistan because both have bitter relations with Iran. After the disintegration of USSR, both Pakistan and Iran had different opinions over the establishment of new government in Afghanistan. Both Iran and Saudi Arabia started supporting different groups in Afghanistan, which provoked alarming situation for Pakistan that was already hosting five million refugees. On the other hand, under the war on terror, Kingdom of Saudi Arabia became an ally of Washington.

In 2017, Jaishul-Adl shot fires resulting into the deaths of 10 Iranian border guards. Because this Saudi backed militant organization used the land of Pakistan to attack these guards, Iranian army head strictly warned Pakistan to confront these radical groups or else they will conduct strikes and hit bases within Pakistan (Dawn, 2017). Once again, the Pakistan suffered at the hands of enmity between the two states. Pakistan is in a desperate need of peace, stability and a friendly government in Afghanistan to cope up these radical and extremist elements.

Yemen war adds fuel in the fire of tensed Iran-Saudi relations. Saudi Arab accuses Iran of instigating the conflict by backing Houthis. Houthis were initially confined to the province of Saada but the events after Iraq's invasion by US, turned them into a violent group. Saudis felt threatened by increasing power of Houthis, which was the demonstration of power by Iran indirectly; they in 2009 used artillery and targeted Houthis forces. This escalated tensions and Iran increased their material and financial aid (Muzaffar et al., 2017).

In 2011, a series of protests accrued which shook the whole MENA region. Rulers who were ruling for decades were over thrown by protests. Condition was alarming for Saudi Arabia because it is a kingdom while Iran was enjoying these changes and its own message of revolution was resonating in the region except Syria where it sided with Bashar-Al-Assad. A power and security vacuum was created in the region and both states were struggling to fill that space. These two states further divided the region and tried to achieve larger gains. But the no state actors being created and supported by these two states to counter each other can change the whole map of the Middle East. Also Iranian nuclear program is perceived by Saudi Arabia as an attempt disturbs the balance of power in the region and eventually the creation of arm race in the region. It was 2011, when the uprising named Arab Spring started. This introduced new political interests and a beginning of new relations concerning Saudi Arabia and Iran both, taking account of their regional interests. Egypt, Libya and Tunisia had dictatorship system, which created a fuss, resulting in deviation in balance of power in the region of Middle East. Unlike Iraqi liberation of 2003, a movement started by United States, Arab Spring 2011 was an inside uprising stating from these three states. It was natives that motivated Arabian mechanism, which waited for political reforms.

Beside fear of sectarianism, Pakistan is aware of the fact that creating disturbance with can increase stake in the region of Baluchistan. In 2016, an Indian spy was caught red handed by Pakistan's Intelligences agencies who as per claim was working to destabilize Pakistan and entered Baluchistan through Iran (Dawn, 2026). This incident has also created anxious situation for Pak-Iran relations. 
A joint project India, Iran and Pakistan gas pipeline was initiated more than two decades ago, India did not continue because of pressure from U.S and Pakistan was also pressurized by U.S and KSA to back out and an alternative project of TAPI gas pipeline was instigate by Saudi Arabia and U.S but it passes through the unstable region of Afghanistan where success rate of this program is not high. There is another project of $\$ 46$ billion China-Pakistan Economic Corridor (CPEC). The CPEC has been charged as a potential distinct advantage for Pakistan as well as for numerous locales in its neighbourhood. However, for the CPEC to work out as intended, security is an absolute necessity. Political insecurity in the district because of SaudiIranian pressures and its overflow into Pakistan can frustrate nation's endeavours to procure the profits of the CPEC (Mumtaz, 2016).

At the end of 2015, Islamic nations have set up a worldwide military coalition, which was toward the beginning being proposed as a worldwide battle against oppression. The alliance includes mostly the Arabs and North African nations, while Iran, Iraq, Syria and Yemen are excluded. Saudi Arabia and the UAE are venturing up their own military reach, even outside of their own zone, for example, the Gulf of Aden and the Red Sea. The last has gotten basic because of the developing impact of Iran in the last district, otherwise known as Yemen. As of late, Iran has tried to build up collusions with Eritrea, Sudan and different nations in the Red Sea district to improve its capacities against two of its key adversaries, Israel and Saudi Arabia, which both have maritime access to the Red Sea. In Yemen, Iran's association is vital, as it likewise has given it access to the Red Sea. Middle Easterner experts are extremely stressed over the likelihood that Iran's naval force could pick up maritime bases access from which it could compromise delivering through the Bab el Mandeb waterway, the Red Sea's southern door to the Indian Ocean. The Horn of Africa is especially significant in light of the fact that it has a 2,500-mile coastline that runs from Sudan in the north to Kenya in the south and near Red Sea and South African Cape oceanic courses (Widdershoven, 2017). Pakistan's ex-chief of Army Staff Raheel Sharif's appointment as Chief of Islamic Military Alliance to Fight Terrorism (IMAFT) started a new debate for Pakistan. But Pakistan made it clear to Iran that Islamabad is never going to a party against Iranian interests. It appears Pakistan anticipates that Iran should comprehend the troublesome monetary situation where in Islamabad gets itself. Iran's diplomat to Pakistan expressed as of late that any ventures by Arab states in Pakistan is Islamabad's inside issue and Iran regards Pakistan's sway. Remarkably, the Pakistan armed force is the main non-partisan armed force in the Muslim world - it has had Shia chief of army staffs, Sunnis and a few Christian officers. Given this, Pakistan is well situated to adjust Iran and Saudi Arabia's strains (Alam, 2018).

Situation became alarming in Middle East after attacks on two of the Saudi Oil fields in September 2019. Iran was held responsible for these attacks. U.S decision to deploy more troops further intensified the situation. Pakistan condemned these attacks but did not blame Iran. Although, Saudi Arabia views Pakistan as a frontline state in the hour of need, but it always managed to escape the pressure exerted by Riyadh to pursue its interests (Jamal, 2019).

\section{Pakistan Struggle for Reconciliation}

Despite all challenges and difficulties, Pakistan is trying to facilitate both regional allies. Strategically Pakistan can play a vital role in the regional issues, as being a nuclear power is another advantage, which raises the bar of Pakistan high. On the other side, Pakistan has deteriorating economy and its in dire need of economic aid. Pakistan and Saudi Arabia share a 
notable economic relation and have a skewed trade balance. 2.5 million Pakistanis are working in Saudi Arabia and sending notable amount to Pakistan as a remittance. According to US trade statistics in 2016, Saudi Arabia imports with Pakistan in term of textile, food like rice, meat and vegetables is about $390 \$$ million. Another $26 \%$ is added for furniture and leather. Therefore, it is in favour of Pakistan to take initiative of reconciliation between Iran and Saudi Arabia. Pakistan can play important role for creation of regionalism in Middle East, which is only possible when Iran and Saudi Arabia have good relations (Shabbir, 2014). Regional organizations like OPEC, GCC and ECO can also play a supportive role. In 2014, PM Nawaz Sharif visited Iran after 16 years. The aim of this visit was to endorse bilateral relations and exchange of views over regional hegemony (Ghoshal, 2015).

Iranian foreign minister stated in a talk in Islamabad "We are ready to work with Kingdom of Saudi Arabia (KSA) on every bilateral and multilateral issue. He said that we know that we cannot exclude Saudi Arabia from this region and it's important for them to also understand this. We need to have a reciprocal understanding that excluding one another from the region is not an option. If Saudi Arabia faces any aggression, Iran will be the first to come to their assistance. We believe the security of our neighbours is our security. Stability within our neighbourhood is our stability" (Public Talk, 2018).

Over Yemen conflict, Pakistan's parliament decided to remain neutral and not to deploy forces through a resolution. Reaction by the Persian Gulf countries was harsh especially Saudi Arabia, United Arab Emirates and Bahrain. However, relations became strengthened again during the last couple of years as new Crown Prince Mohammad Bin Salman decided to improve bilateral relations with Pakistan. There are some major reasons behind this approach; most important amongst all is Pakistan's domestic military support to Saudi Arab and other Gulf states. Pakistan deployed some troops in 2018. On the nature of deployment, ISPR said that "These troops will not be employed outside Saudi Arabia. Pak Army maintains bilateral security cooperation with many other GCC countries (Syed, 2018). Yemen's President Ali Abdullah Saleh handed over his power to Abdrabbuh Mansoor Hadi after Arab uprisings. However, in 2015, Houthis captured the capital city of Sanaa and Aden was deposed. Since then an eightnation coalition started bombing using Saudi Land to counter Iranian influence in the region (Khan, 2019). Pakistan did not accuse Iran one-sidedly, rather Prime Minister of Pakistan Imran Khan urged both states to deescalate their tension through dialogue. According to a statement of Pakistan's foreign minister "We urged them (Saudi leadership) not to rush into decisions that could hurt peace and stability of the region." In a nutshell, Saudi Arabia cannot look forward for cooperation by Pakistan, which could challenge Iran's interests because it can create hurdles in Pakistan's domestic factors and provoke sectarianism (Jamal, 2019).

In 2019 some important agreements of worth \$20 billion were signed between Pakistan and Saudi Crown prince Mohammad bin Salman during his visit to Pakistan (Dawn, 2019). Second, Riyadh is well aware of the geopolitical sensitivity and thus Pakistan's neutral stance over Yemen. In September 2019, the two oil fields (Abqaiq and Khurais) were attacked and Saudi Arabia blamed Iran for attack and backing the Yemini Houthies. Both countries were at the brink of a war but Pakistan condemned the attack and Pakistani PM Imran Khan visited Iran and Saudi Arabia to settle down the issue (Shariq, 2019). Pakistan's decision of mediations between Riyadh and Tehran proved to be successful which scrubbed off all doubts shown by a few entities over the success rate of this effort. Meanwhile, Tehran also wished to arrange a meeting between the two states and both states responded positively over mediation offer along 
Pakistan's Exertions of Reconciliation between Iran and Saudi Arabia: Challenges and ...

with the appointment of a focal person by Pakistan, Iran and Saudi Arabia would also be contacted to do so. These sincere efforts of Pakistan were highly appreciated by all other Muslim states. Pakistan did not stand up for the first time to play the role of a mediator but it tried for mediation during Iran-Iraq war (1980-1988). Also, in 1997 during the side-lines of OIC Summit Pakistan's effort made it possible to arrange an ice-breaking meeting between King Abdullah and Hashmi Rafsanjani the then Iranian president. Any conflict between Iran and Saudi Arabia provokes sectarian conflict in Middle East and Pakistan becomes more vulnerable to such conflicts as it has the history of sectarian violence.

\section{Conclusion}

Middle East is considered the centre of world politics. It is one of the regions in world where no state exists without a rival. A famous saying is that one can choose his friends but not neighbours. This describes the dilemma that shaped Iran-Saudi rivalry for almost a century. Creation of Islamic military counter terrorism alliance led by Saudi Arabia in 2010 and Yemen war in 2015 were two major events, which escalate division between Iran and Saudi Arabia. Pakistani elected leadership decided to remain neutral and national assembly of Pakistan refused to be part of Saudi invasion of Yemen but meanwhile Pakistan joined the Saudi-led military alliance again terrorism. In 2017, a major policy shift in US policy towards Iran under US President Donald Trump effected Islamabad's calculations and foreign policy towards both respective states. The split between Iran and Saudi Arab is not only the power struggle and regional hegemony but it has cultural, religious and ideological aspects. Pakistan is alley of both as Iran is an immediate neighbour of Pakistan and share the border with its most sensitive province Baluchistan. In hard times, Saudi Arab always stood by Pakistan. Therefore, Pakistan cannot upset one for other and always try to manage its relationship with both states. Pakistani leadership's efforts to mediate between two Middle Eastern powers' conflict are therefore timely. It is important for Pakistan to maintain strong traditional ties and solidarity with Saudi Arabia because it has stood by Pakistan through thick and thin. At the same time, after the USIran rapprochement, new avenues are opening up for Pakistan, especially the completion of the Iran-Pakistan gas pipeline, cooperation in the energy sector, enhanced trade and collaboration in the CPEC. All these new opportunities should be seized, and should not be allowed to become a victim of the turmoil in the Middle East. Pakistan should stay the course of a balanced policy towards two major Middle Eastern powers, and continue to demonstrate moral high ground by pursuing diplomacy for mediation and conciliation. Keeping in view Pakistan relations with Arab's and Persian state United Nation Secretary General Ban Ki Mon said that Pakistan could play a positive role to maintain peace in Middle East (Muzzafar, 2017). Despite all challenges and enmity, Saudi Arab and Iran are considering to established good relations with each other. It is only possible by initiating positive steps and cooperation. Both states should adopt trust building measures and to stand firm for peace and stability in the region. Pakistan views both as a close friend and as struggling hard to create a bridge between them. Following are the recommendations and some suggestions for Pakistan's facilitation between Saudi Arabia and Iran.

In the current world politics, only the cooperation is rewarded, not the defection, therefore, Pakistan offered itself to bridge the gulf between Iran and Saudi Arabia keeping in view peace and stability of the Middle East and rest of the region. Whenever there was a need of Pakistan in any of the crises, Pakistan has been in the front line for Saudi Arabia. Pakistan has critically helped Saudi Arabia in "Looking East" Policy as a stepping-stone. Similarly being a close 
neighbour, Pakistan value relations with Iran with great significance and want to maintain the cordial relation with Iran and Pakistan do not want any rift of two major sects of Sunni and Shia in Pakistan. Pakistan has stepped up to neutralize the escalating tension between Iran and Saudi Arabia. There is a fundamental shift of International Order from geo-strategic towards geo-economics as described by Luttwak (1990) in post-cold war politics scenario, this paradigm is based on the interdependence, and cooperation and convergence, which is rewarded, whereas divergence and defection is punished the system. Therefore, the regional politics has become the determining factor for economic dividends of the region. The regional issues needs resolution at regional level and in such an escalation of tension between two Middle Eastern countries, Pakistan had shown a gesture peace and stability through facilitation to open a dialogue between the two countries as the dividends of peace and stability has be reached to the whole region. Pakistan also view the regional instability as the hindrance of its foreign policy objective to engage positively with India, to play role in bringing peace in Afghanistan and make more stakeholders in peace and stability in the region and to deescalate tensions. Pakistan is taking its pursuing the objective of peace and stability in the region through its proactive foreign policy object as an opportunity cost after scarifying thousands of human loss along with billions of dollars loss in economy for bringing peace and stability. This is not important only for the political but also for economic relations and development, as investment has become the engine of the growth presently and no region and country would attract domestic and international investment unless there is peace and stability. Following are key Recommendations of the study:

a) KSA and Iran should ignore insignificant issues and cooperate for the larger interest of states.

b) The prosperity of the Middle East is directly connected with the cordial relations between Iran and KSA. Therefore, both should consider economic and strategic challenges and focus to resolve the issues.

c) Pakistan being a trustworthy friend of both states should come up with determination and natural approach to help in narrowing the gulf.

d) The issues regarding regional hegemony and proxy wars fought by Iran and Saudi Arabia should convert into trade and economic cooperation.

e) Both states should not compel other Persian Gulf States to be part of gaining power.

f) Pakistan, Iran and Saudi Arabia should strengthen OIC to unite other Muslim states and should play a leading role commonly.

\section{References}

Ahmed, A. (2019, June 11). Pakistan budget. Gulf News.

Alam, K. (2018, February 18). Asia's quiet superpower: Pakistan army's teetering balance between Saudi Arabia and Iran. Middle easy eye. https://www.middleeasteye.net/opinion/asias-quiet-superpower-pakistan-armysteetering-balance-between-saudi-arabia-and-iran.

Calvocoressi, P. (2001). World Politics, 1945-2000. Essex: Pearson Education.

Cordesman, H.A., \& Kleiber, M. (2008, August/September). Iran's 'invisible man'. The Middle East

Cordesman, H. A., \& Kleiber, M. (2007). Iran's Military Forces and Warfighting Capabilities: The Threat to the Northern Gulf. CSIS 
Pakistan's Exertions of Reconciliation between Iran and Saudi Arabia: Challenges and ...

Dawn (2015). UAE minister warns Pakistan of 'heavy price for ambiguous stand' on Yemen. Ghoshal, D. (2015). Pakistan Keen to Keep Ties with Iran and Saudi Arabia. Yale Global and the MacMillan Center, 8.

Grumet, T. R. (2015, January 01). Digitals Commons. https://digitalcommons.du.edu/etd

Iqbal, K. (2010). Tehrik-e-Taliban Pakistan: A Global Threat. Conflict and Peace Studies, 3, 125-138. Taliban_Pakistan_A_Global_Threat

Jamal, U. (2019, September 24). Pakistan's Approach to Navigating Saudi-Iran Tensions: Solidarity with Riyadh. The Diplomat.

Khan, S. J. (2019, October 13). The Saudi-Iran conflict and Pakistan. The Express Tribune.

Khan, M. N. (2001). The US policy towards the Persian gulf: Continuity and change. Strategic Analysis, 25(2), 197-213. https://doi.org/10.1080/09700160108458951

Luttwak, E. N. (1990). From geopolitics to geo-economics: Logic of conflict, grammar of commerce. The national interest, (20), 17-23. https://www.jstor.org/stable/42894676?seq=1

Muzaffar, M., Khan, R., \& Yaseen, Z. (2017). Saudi-Iran Strife: Complexities for Pakistan. Global Regional Review, 2(1), 119-134. http://dx.doi.org/10.31703/grr.2017(II-I).03

Mumtaz, K. (2016). Pakistan's Mediation Efforts in Saudi-Iranian Tensions. Institute of Strategic Studies, p. 2-3. http://issi.org.pk/wp-content/uploads/2016/01/Final-Issuebrief-kashif-dated-27-1-2016.pdf

Nasr, V. (2006, August 13). Muslims against Muslims. The New York Time

Riedel, B. (2010, December). The Mideast after Iran Gets the Bomb. Current History. p. 370375.

Sajjad, S. B. (2018, February 16). Army Says troops being sent to Saudi Arabia. DAWN.

Sattar, A. (2013). Pakistan foreign policy: A concise History. Oxford University press.

Shabbir (2014). Pakistan's Potential Role vis-à-vis Arabian and Persian Flanks of the Gulf. ISSRA, 18.

Panda, A. (2019). Pakistan's Approach to Navigating the Saudi-Iranian Split. United States Institution of Peace.

Widdershoven, C. (2017). Military Alliance Arab States to Confront Iran Soon? Reality and Disagreements Hitting Capabilities. Energy Policy Turkey, (3), 13-27.

https://dergipark.org.tr/en/download/article-file/344813

Yemen's War: Pity those caught in the Middle. (2009, November 21). Economist. https://www.economist.com/middle-east-and-africa/2009/11/19/pity-those-caughtin-the-middle.

Public Talk (2018). 70 Years of Pakistan-Iran Relations and Future Prospects. Islamabad: ISSI. 